\title{
MYCOLOGICAL NOTES I 1
}

\author{
Rafael A. TORO \\ (With one plate and one figure on the text)
}

The purpose of these notes is to present the results of the studies of the mycological flora of the Island of Porto Rico. The bulk of the literature already in existence on this subject contains several disagreements regarding the identity of some of the forms studied, and makes necessary a detailed and comprehensive revision of some of the groups.

The study of the tropical flora has been for a long time a subject of interest to those engaged in botanical classification of phanerogams, although, from the start, some eryptograms were incidentally col. lected and studied. The fungi collected in Porto Rico by P. Sintenis in 1881 were studied by Bresadola, Hennings and Magnus (Eng. Bot. Jahr. 175: 489-501. 1893.) and recorded by Stevenson (Journ. Dept. Agric. Porto Rico 23: 125-264. 1918.). Those collected by C. Schwanecke in 1846 were studied by Klotseh (Linnea 25: 364-366. 1852.) and also recorded by Stevenson. We find in Stevenson's paper a record of only one of the fungi collected by Bertero in 1818 . This fungus was described by Léveillé (Ann. Sci. Nat. $3^{2}: 177$. 1844.) under the name Heliomyces berteroi sp. nov. and was restudied and transferred by Murrill (N. Am. Fl. 9': 267. 1913.) to Marasmius berteroi (Lev.) comb. nov. However, other fungi were also collected by Bertero and described by Montagne (Amn. Sci. Nat. $8^{2}: 345-470$. 1837.) and Léviellé (Ann. Sei Nat. $3^{3}: 38: 77$. 1845.) but not recorded by Stevenson. Montagne is, apparently, the first scientist to describe a fungus from Porto Rico. By way of introduction to these notes and as a matter of historical interest in mycology a presentation is here given of this description by Montagne:

"36. Dothidea (Asteroma) Eugeniac (Montag. mass.); amphigena, maeulaeformis, centro opaca atra fibrillis ramoso-pinnatis, ramis patentibus in ambitu radiata, cellulis confertis minimis collapsis ostiolo instructis.

"lab. in foliis vivis cojusdam Eugeniae speciei in Porto Rico a Bertero et mecum sub nomine Depazeae engeniae a Balbisio communicata.

\footnotetext{
1 The writer wishes to acknowledge his olligations to Dr. F. J. Seaver of the New York Botanical Garden for the facilities rendered during the writer's stay at that Institution and to Dr. Mel. T. Cook for reading and correction of the manuscript.
} 
"Dlegans uti sunt pleraeque species hujus tribus. Maeulae amphigeneae, variae amplitudinis, confluentes, saepius minimae, 1-2 lineas latae, centro opacae, ambitu fibrillis tenuissinis atriculatis ramoso-pinnatis, ramis alternis decreseentibus radiatae. Cellulae praesertim in centro maeularum confertae, sed tamen distinctae, minutissinae, collapsae, pezizaeformis, enmorphae, ostiolo sub vitris augentibus tantum conspieuo instructae et sat similes peritheciis Sphaeria con. planatae Tode, a quibus mole solum primo intuitu recedunt."

This fungus is also recorded by Saccardo (Syll. Fung. 1: 49. 1882.) in his section Asteridium under the name of Asterina engeniae Mont. It can not be an Asterina since Saccardo states in the description that the spores are three-septate. Theissen (Abh K. K. Zoo-Bot. Ges. Wien $7^{3}: 25$. 1913.) also excludes the species from Asterina Lév, because "Nach der Beschreibung sind die Sporen vierzellig". The writer examined a specimen from South America, deposited in the herbarium of the New York Botanical Garden and labelled Dothidea Eugenice Mont., and found that there are no asei or spores on the fungus.

Léveille describes two other fungi from Bertero's collection: Sphaeria ecastophylli sp. nov. on leaves of Pterocarpus Ecastophyllum and Stilbum borteroi sp. nov. on dead twigs. The first species was transferred by Saccardo (Syll. Fung. 1: 44.6. 1882.) to Physalospora Ecastophylli (Lév.). The other species is still known under its or iginal name. In his paper, Lévielle reports for the first time from the Island, Mcliola amphitricha Fr. on leaves of Aralia arborea. This fungus may be the same as Meliola aralic collected in 1884 in Porto Kico on leaves of Dendropanax arboreum (L.) Dene. y Pl, and reported by Stevens (Illinois Biol. Monog. 2: 505. 1916.).

1. Calothyrium Ingae Ryan.

The genus Calothyrium was established by Theissen (Ann. Myc. $10: 160$. 1912.) to include those species formerly assigned to Asterina Lév. having hyaline spores and mycelium devoid of hyphopodia. F'or the brown-spored forms the new genus Asterinella Th. was also proposed.

According to Arnaud (Les Asterinées 1: 150. 1918.) the generic characters of Microthyrium Desm. were not well delimited. He found that the type-species, M. microscopicum Desm., is provided with superficial mycelium and resembles in general characters Asterinella Puiggarii (Speg.) Th. For this reason he amended the description of Microthyrium Desm., including among its characters the presence of superficial mycelium. The writer examined at the New York Botanical Garden a specimen labelled "Microthyrium 
microscopicum Desm". (Rab. \& Wint. F. Europ. No. 2943) and found that it has a very scanty superficial mycelium. Undoubtedly the genera Calothyrium Th. and Miorothyrium Desm. are the same, while Asterinella Th. differs from either only in having colored spores. The genus Calothyrium Th. then becomes a synonym of Microthyrium (Desm.) Arnaud. Therefore, Calothyrium ingae Ryan becomes Microthyrium Ingae (Ryan) comb. nov.

On leaves of Inga Inga (L.) Britton. Porto Rico Fungi (Stevens). No data.

Spots none; colonies more or less circular, 5-10 mm, in diameter, membranous, black at the center, pale toward the edges; mycelium without hyphopodia, 3n. in diameter, straight, rarely anastomosing, light brown, septate; $90-110 \mathrm{n}$. in diameter, astomous at first, ostiolate at maturity and dehiscing by desintegration of the cell walls, fuliginous, coriaceous, finely denticulate at the borders, prosenquimatousradial, with thin, searcely septate straight threads; asci oval-obovate, 14-18 $\times 14 u$., 8-pored, thick-walled and roundish at the upper portion sub-cuneiform at the lower and terminating in a thick, short pedicel; spores inordinate, cylindric-fusoid, 10-12 × 2-3u., 1-septate, the superior cell obtuse, sub-globose, the inferior acute, slightly constricted, hyaline; paraphyses filiform, mucilaginous.

C. Hippocratece Ryan may, according to the description, also belong to Hicrothyrium Desm. Since no material of this fungus has been available it is temporaly left under the former.

2. Microthyrium Psychotriae (Ryan) comb. nov.

The fungus Calothyrium Psychotrice Ryan is also a Microthyrium. It forms no spots on the leaves but the subiculum consists of rather irregular, black crusts $2-5 \mathrm{~mm}$. in diameter; the thiriothecia are 110-115u. in diameter, opaque-fimbriate, provided with ostiolo but dehiscing by desintegration of the radiate hypha which make up the perithecial elements; the mycelium is brown, 4-6u. thick, closely septate and nearly straight; the asci round, sessile, the upper portion very thick-walled, the lower thinner, 12-20u. in diameter, 8-spored; spores inordinate, elliptical, 2-celled, 5-7 $\times 2-3$ u., hyaline (Plate I, Figs. 4 \& 5.).

On leaves of Psychotria sp. Porto Rico Fingi (Stevens) No. 6662.

3. Lembosia microspora Chardón and Morenoella portoricensis Speg.

The genus Lembosia Lév. differs from Morenoella Speg. in having 
asci provided with paraphyses. The descriptions of Lembosia microspora Chardón (Mycologia 13: 282. 1921.) and of Moronoella portoricensis Speg. (Bol. Acad. Nac. Ci. Córdoba 26: 343. 1923), however, state that paraphyses are present in both species. The writer has examined several specimens of these two fungi and has found that the presence or absence of paraphyses is a very unstable character on which to determine the generic position of these species. According to the stage of maturity of the fungus, one will find sometimes distinct, sometimes few, or sometimes no paraphyses. The same has been found to apply to genera which are differentiated by their variations in structure of the free mycelium, for instance, as to the presence or absence of mycelial sete or hyphopodia. So differs Ireno Th. \& Syd. from Moliola Fr. In Irone the mycelial setw are wanting while they are present in Meliola. But from the examination of fresh material in the tropies the writer is convinced that Irene species with mycelial structures resembling setre may also nceur as Mcliola with typical setre, and vice versa, depending upon weather conditions, character of the host and stage of development of the fungus. Such genera, and many others, therefore, have very low value, but they considerably increase the already existing uncertainty and will frequently cause errors. It would be much better and more in accordance with natural conditions if such genera would only be considered as sub-genera. The writer (Mycologia 17: 131-147 . 1925.) recognized the genus Irene Th \& Syd. as having welldefined characters, but only forms which do not show tra es of tyj $\mathrm{i}_{\mathrm{a}} \mathrm{al}$ setwe and have no mycelial structures resembling them, are considered. Ifowever, after more extensive studies it may possibly be found that even the complete absence of sete is not a stable character, in which case it will be necessary to consider the genus as a section of the older genus Meliola Fr. The same may be applied to Appendiculella v. Höhnel, which differs from Mcliola Fr. in the presence of vermiform perithecial appendages.

In his description of Lembosia microspora, Chardón makes the statement that hyphopodia are absent. However, upon re-examination of his type and other material it has been found that there are very distinct hyphopodia on the mycelium, although sometimes these are wholly absent. It was also noticed that these hyphopodia can be very easily mistaken for the basal cells of broken mycelial l.yphæ which remain attached after the rest of the hyphæ have been 
separated. They are cylindric, 1-celled, pointed toward the ends and of the same color as the mycelium.

From the studies of the type-materials of Lembosia microspora Chardón and of Morenoclla portoricensis Speg., the writer found that the dimensions of the different elements overlap and that there is no difference between the species. Also since they have the same general characteristic and occur on the same host there is no doubt that we are dealing with the same fungus in both cases. The name given by Chardón must be retained as valid for reason of priority, but the description needs to be emended.

Limibosia Mrtcrospora (Chardón) char. emend.

Lembosia microspora Chardón, Mycología 13:282. 1921.

Morenoella portoricensis Speg., Bol. Acad. Nac. Ci. Córdoba $26: 343.1923$.

Echidnodes microspora (Chardón) Seaver \& Toro. Sci. Surv. Porto Rico $8: 41.1926$.

Spots none; colonies amphigenous; mycelium widely spreading, septate, 3-4u. in diameter, light-brown, branched, anastomosing; hyphopodia straight-cylindric or sub-ampulliform, small, 1-celled; thyriothecia seattered, black, often curved, 200-800×100-200u.; asci obovate-ellipsoidal, 8-spored, 18-25 $\times 15-20$ u.; spores inordinate, 1-septate, constricted at septum, $10-15 \times 4-5 u$., hyaline at first, becoming dark-brown with age; psendoparaphyses present.

On leaves of Ocotea leucomylon (Sw.) Mez. Cornell University Explorations of Porto Rico (Whetzel \& Olive) 621 (Type of Chardón's species); Porto Rican Fungi (Stevens) r56.3, 4762, 845.9, 9433 (Type of Spegazzini's species according to Ryan, Mycologia 16: 193. 1924.), 4739, 9436, 9422, 7349, (Deposited in herbarium New York Botanical (Garden).

Colonies thinly diffuse, more or less round, 5-20 mm. in diameter; raycelium thin, 3-4u. in diameter, straight, frequently anastomosing and at right angles to the hyphe, light-brown, septate; hyphopodia numerous, generally opposite, at right angles to the mycelial hyphr, cylindric and pointed toward the ends, 8-12 $\times 3-4 u$, 1-celled, lightbrown; thiriothecia linear, 200-800 $\times 100-200$ u. scattered, dehiscing by a longitudinal slit, black, border's fimbriate, of thin, $2-2.5 \mathrm{u}$. thiek, light-brown hyphie; asei obovate-ellipsoidal, 18-25 $\times 15-20 \mathrm{n}$., thickwalled at the upper portion, thinner at the lower, 8-spored; spores inordinate, cylindrie, 10-15 × 4-5u., unequally 1-septate, constricted at septum, hyaline at first, becoming dark-brown with age; pseudoparaphyses filiform, numerous. 


\section{Eeprieurina radiata $\mathrm{sp}$. nov.}

Spots none; fungus amphigenous, forming black, irregular crusts :-20 mm. in diameter; pyenidia round, radial, 210-225u. in diameter, formed of light-brown cells about $12 \mathrm{u}$. long and $3 \mathrm{u}$. thick; ostiolum small, round, 10-12u. in diameter; mycelium dark-brown cob-webby, non-hyphopodiate, 6-8u. wide; coniodophores inconspicuous, 2-5u. long, hyaline; spores one-celled when young, hyaline, kecoming two celled with age and with an olivaceous tint, oblongolliptic, 9-16 $\times 3-5$ u. (Plate 1 fig. $2-3$ ).

On leaves of chrysobalamis icaco L., Loíza, P. R. Herbarium R. A. Toro 428 (Type).

The microscopical characteristics of this fungus is microthyriaceous and it is undoubtely a pycnidial form of one of the genera of this ascigerous group. The pyenidia are dimidiate and inverse-radiate like the perithecia of the Microthyriacer. They are solitary or in groups, posses an ostiolum but dehisce by desintegration of the walls. The mycelium is devoid of hyphopodia, like the mycelium of the ascigerous genus Asterinella, and forms a net of eross-webby threads by the anastomosing of the hyphr. The spores arise from underneath the upper part of the pycnidia and very often, the small inconspicuous conidiophore remains attached (Plate I, fig. 3 ) so that it gives the spore the appearance of being ciliate. A character which makes this fungus very distinct from any other form thus far described is that the spores are oblong-elliptic instead of pyriform as is the ease with the other species.

The systematic position of the genus Lepricurina is uncertain It has the same characteristics as Asterostomella, a fungus deseribed by Spegazrini (Fungi Guaranitici 1: 157. 1883.) and originally placed by him among the Leptostromatacea of the Fungi Imperfecti. He indicated that Asterostomella is a pyenidial form of Asterine. There is no family among the Fungi Imperfecti that would accomrodate the inverse-radiate, superficial pyenidial forms of the Microthyriacea. The abundance of superficial mycelium and the character of the pyenidium makes the group unlike any other of the Fungi Im. perfecti. Arnaud (Les Asterinés 1: 204. 1918.), realizing this fact, proposes the family Microthyriopsidees for this group including the genus Asterostomella as type, and characterizing the genus as having colored-spores. Lepriourina Arnaud is also placed on this group, differing from Astorostomella in having 2-celled spores. 


\section{Perisporium Bromeliae Stevens.}

Perisporium bromelice is described by Stevens (Trans. Illinois Acad. Sci. 10: 168. 1917.) on leaves of Bromelia Pinguin L. This most interesting fungus was placed in this genus with some uncertainty as it slows relationship with different genera of the Perisporiacea and Sphaeriacex, although sufficiently distinct from either to constitute a new species. Stevens (1. c.) places the species under Perisporium Fr. since it agrees most closely with this genus although it differs in having 4-spored asci.

The writer compared the type-species of Perisporium bromelice Stev. (Stevens, Porto Rico Fungi No. 4329) with a specimen of "Asteridium dimerosporioides Speg. (C. Ronmerguére Fungi selecti exsiccati No. 5244) deposited in the herbarium of the New Botanical Garden and found them to be the same. This fungus, described by Spegazzini (Fung. Guar. II: 50. 1888.) on leaves of Caraguata sp., was transferred by Saccardo (Syll. Fung. IX: 434. 1891.) to. Zulkalia dimerosporioides (Speg.). Later, v. Höhnel (Frag. zur Myk. 157: 617-618. 1917.) disensised fully the affinities and relatronships of Asteridium dimerosporioides Speg. and placed it on the Hiypocreales under the new combination Gibberella dimerosporioides (Speg.).

Recently, González Fragoso and Ciferri (Rev. Soc. Española Hist. Nat. 25 : 499 . 1925.) described and illustrated Chaestosphaeria bromelice sp. nov. on leaves of Bromelia peregrina. However, several collections of this same fungus, on Bromelia Pinguin L., were made in Santo Domingo by Kern and Toro. They were shown to Dr. Ciferri and he said the fungus is the same they had described as Chaetosphaeria bromelio. This fungus, on the other hand, was. compared by the writer with Perisporium bromelice Stevens and found that they are the same. There is, nevertheless, some inconsistency in the statements regarding the number of spores in the ascus. González Fragoso and Ciferri say the ascus is 8-spored; Stevens says it is 4-spored. This same disagreement exists on the discussions of Spegazzini and v. Höhnel. Sydow and the writer have found that the asci are 4-spored instead of 8-spored. It is not surprising that the asei may appear as being 8 -spored, since their walls are evanescent and when one ascus lies over the other and their walls desintegrate it gives the appearance as of being twice. the actual number of spores. This same observation is made by $v$ : 
Hömel and he says that "Spegazzini gibt die Asei vier-bis achtsporig an; docb wird dies ein Irrtum sein, da in $50 \times 25$ u. grosen. Asei liaum acht 26-8u. grossen Sporen Platz haben. Ich fand die Asei stets viersporig, doeh wenn zwei Asei übereinander liegen, kann man sie leiclt fitir achtsporig halten."

The setze observed on the perithecium by González Fragoso and. Ciferri may be due to an error of vision. The writer has always found that the mycelium consists of rather stiff, seta-like, septate hyphe growing more or less horizontally to the subtratum and occurring only at the furrows between the veins of the leaf; but

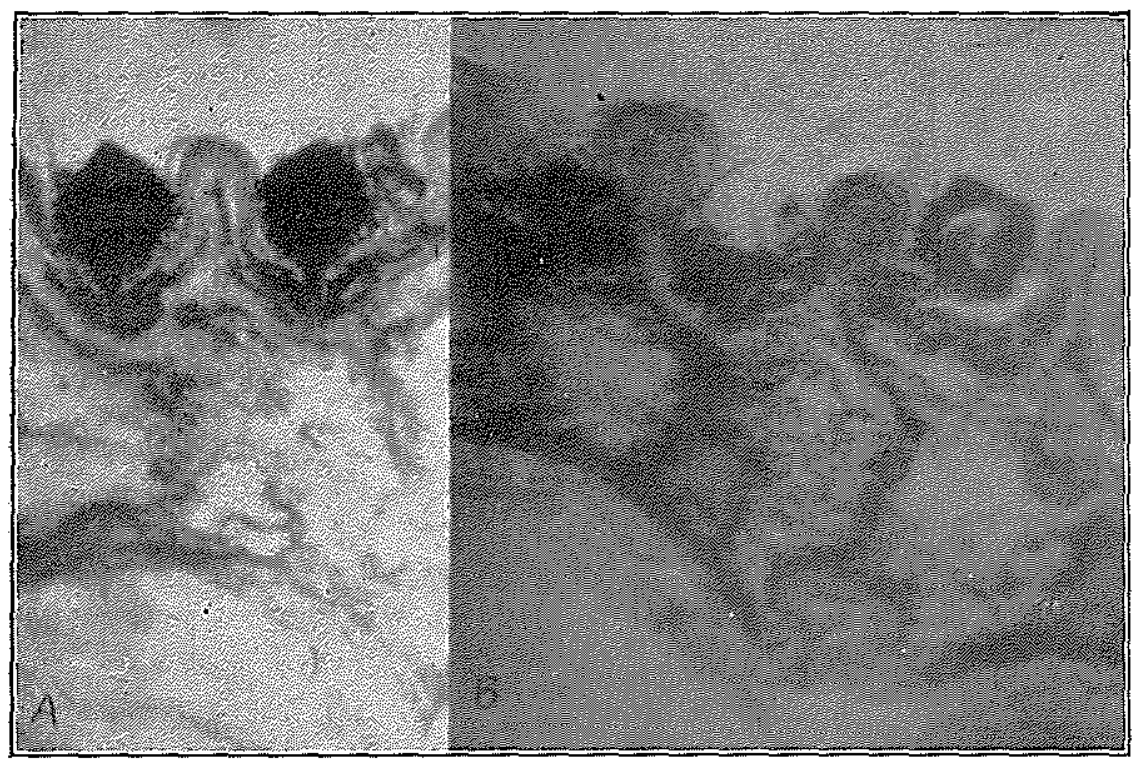

Frgune 1.-Photomicrograph of a cross-section of a leaf of Bromelin l'inguin L. blowing the position of the perithecia of Torod dimerosporioides. (A) Perithecia between the veins of the leaf. Notice the setre-like myeelial hyplag fitintly shown on ihe left-luat side of the first perithecium. (13) Cross-ssetion of a perithecium. $\times 96$.

never arising from the perithecium. The perithecium is provided with a papilla and dehisces at maturity by desintegration of the cell-walls. These characters are unlike any other' hitherto deseribed for a fungus of this group and are suffirient to justify the establishment of a new genus. Noreover, the type of the genus Perisporin Fr., P. gramineum Fr., is, according to Saccardo (Syll. Fung. I: 56. 1882.), synonymous with (rocicreas Fr., one of the Excipuleae; the type of Asteridium Sacc., A. plourostylix Sacc., is a Meliola according 
to Theisseen and Sydow (Ann. Myc. 15: 424. 1927.); while Zukalia Sace. is synonymous with Chatothyrium Speg. (Theissen and Sydow 1. c. 477.). From the standpoint of modern procedure in nomenclature the generic names Perisporium Fr., Asteridium Sace. and Zukalia Sacc. has no standing whatever and must be abandoned. However, Spegazzini (Bol. Acad. Nae. Ci. Córdoba 26: 348. 1923.) claims that the name Asteridium Sace. is to be retained since Saccardo when establishing the genus had in mind a dimidiate perithecium and not a cleistocarpus one as is the fruiting body of Meliola $\mathrm{Fr}$. $\mathrm{He}$, therefore, emends the characters of this genus, re-establishes the name and places it in the Dyctiopeltinex of the Hemisphriales. It is an undeniable fact that such procedure can not be accepted since it is impossible that Spegazzini could have been able to ascertain what Saccardo had in mind when he established the genus Zukalia, and moreover, such abstract-concept genera, supposing we accept this as one, are not altogether recommendable as they very often cause confusion. There is no doubt also that the fungus is not a Gibberella since its characters do not agree with what we understand as such.

Abundant material of Perisporium bromelice Stev. was collected in Porto Rico and sent to Dr. II. Sydow. After examination of this and some of Stevens' duplicates he decided that this fungus is a new gemus and described it as follows:

Toroa Syl. gen. nov.

Myzel oberflächlich, fleckenförmige oder ausegebreitete schwärzliche Überzïge bildend, teils aus anliegenden meist stark gekrümmten, teils aus etwas abstehenden und riemlich steifen Hyphen bestehend. Hyphopodien fehlen. Perithecien in Hyphenfilze des Myzels nistend, alissen, besonders unten, von demselben bekleidet, ziemlich klein, kuglig, völlig geschlossen, aber fast immer mit deutlicher flacher Scheitelpapille versehen, bei der Reife zerfallend. Hembran brüchigkohlig, mehrzellschichtig, fast opak schwarzbraun. Asci dickwandig, aber leicht zerfiiessend, dick keulig, 4-sporig, sitzend. Sporen breit lünglich-spindelförmig, ziemlich gross, mehrzellig, durchscheinend olivenbraun. Paraphysoiden sehr spärlich, undéutlich faserig-zellig. (Mycelium superficial, forming blackish crusts, hyphæ slightly bent or stiff; hyphopodia wanting; perithecia seated on the mycelium, spherical, nearly always provided with a papilla, dehiscing at maturity 
by desintegration of the cellwalls; membrane brittle-carbonaceous, composed of many layers of cells, black-brown; asci thick-walled, evanescent, ovate, sessile, 4-spored; spores oblong-spindleform, manycelled, translncent, olive-brown; paraphyses sparse, indistinct, filiform.)

Toroa differs from Meliola Fr. chiefly in its papillate perithecia and in the shape, color and septation of the spores.

Type species the following:

Toroa dimerosporioides (Speg.) Syd. comb. nov.

Asteridium dimesrosporioides Speg. Fungi Guaranitici II:

17. 1888.

Zutcalia dimerosporioides (Speg.) Sace., Syll. Fung. IX: 434. 1891.

Gibberella dimerosporioides (Speg.) v. Höhnel, Sitz K. Akad. Wiss. Wien 116: 617-618. 1917.

Perisporium Bromeliae (Stev.) Trans. Illinois Acad. Sci. 10: 168.1917.

Chaetosphaeria bromeliae Frag. \& Cif: Bol. R. Soc. Española Hist. Nat. 25: 449. 1925.

Myzel oberflächlich, nur hypophyli, bald ziemlich kleine, ganz unregelmässig eckige ca. 1-1.5 cm. grosse, schwä1zliche, ziemlich scharf begrenzte Flecken, bald mehr oder: weniger weit ausgebreitete, oft grosse Teile des Blattes gleichmässig überziehende, grauschwärzliche, ziemlich lockere wollig filzige überzüge bildend, aus dümnwandigen der Epidermis anliegenden durchscheinend olivenbraun gefärbten, ziemlich kurzgliedrigen, ea. 3-5u. dicken, meist stark und verschieden gekrümmten Hyphen bestehend, von welchen sich dünnwandige, durchscheinend schwarzbraune, ca. 3-4u. dicke, bis über 600u. lange, mehr entfernt septierte, ziemlich steife, wirr durcheinanderlaufende, fast borstenartige Hyphen erheben, aber bald eine zur Oberfläche des Substrates mehr oder weniger horizontale Richtung einnehmen und ein in den Furchen zwischen der Nerven bis ca. 100u. hohes, ziemlich lockeres Geflecht bilden, in welchen die Perithecien nisten. Perithecien nur in den Furchen zwischen den Nerven in lockeren oder dichten parallelen Längsreihen wachsend, meist ziemlich regelmässig rundlich, ca. 80-130u. im Durchmesser, vollständig geschlossen, aber mit einer flachen, gestutzt kegelförmigen oft ziemlich undeutlichen Papille am Scheitel, bei der Reife meist ganz zerfallend. Peritheciummembran brüchig-kohlig, aus einigen Lagen von fast opak schwarzbraunen, mehr oder weniger zusammengepressten sehr - unregelmässig eckigen, ziemlich dïnnwandigen, etwa 4-7u., seltener 
bis ca. 10u. grossen Zellen bestehend, aussen durch schwach vorspringende Zellen und kleine Zellkomplexe sehr feinkörnig rauh, besonders unten locker mit Hyphen des Myzelfilzes besetzt, innen rasch in eine dümne hyaline oder fast hyaline undeutlich konzentrisch faserige Schicht übergehend. Asci in geringer Zahl, dickkeulig oder länglich ellipsoidisch, am Scheitel etwas vorgezogen, mit stark verdickter Scheitelmembran, stumpf abgerundet, nach unten hin stark erweitert, dann plotzlich zusammengezogen, sitzend oder sehr undeutlich und kurz gestielt, dickwandig, aber leicht zerfliessend, 4-sporig. Sporen ziemlich breit länglich-spindelförmig, beindendig ziemlich starks und gleichmässig verjüngt, stumpf abgerundet, gerade oder schwach sichelförmig gekrümmt, mit 2 ungefähr im oberen und im unteren Viertel der ganzen Länge befindlichen Querwänden versehen, nicht oder nur sehr undeutlich eingeschnürt, mit ziemlich grobkörnigem Plasma oder mit 1-2 undeutlichen aber ziemlich grossen Oltropfen, die mittlere Zelle meist ca : 15-17u. lang tonnenförmig durchscheinend olivenbraun, die beiden Endzellen etwa $7-S u$. lang stumpf konisch und meist deutlich heller gefärbt, im ganzen 25-36u. lang, 9-11u. dick, Paraphysoiden sehr spärlich, undeutlich, faserig zellig. (Mycelium superficial, bypophyllous, forming small, irregularly angled, black, definite spots about 1-1.5 $\mathrm{cm}$. in size, sometimes confluent to form larger spots: outer walls of the host epidermis stained brown; hyphre thin-walled, translucent, black-browm, 3-4 thick, up to $600 \mathrm{u}$, long, septate, somewhat stiff, bristle-like, more or less horizontal to the substratum and then about $100 \mathrm{u}$. high, always on the furrows between the veins of the leaf and with the perithecia seated on them; perithecia in loose or compact longitudinal rows, spherical, 80-130u. in diameter, astomous but with a conical papilla, dehiseing at maturity by desintegration of the cell-walls; membrane black-brown, cells thin-walled, 4-7u. large; asci few, ovate or elongate-ellipsoid, thickwalled at the upper portion, sessile or with a very short pedicel, evanescent, 4-spored; spores oblong-fusiform, straight or slightly "urved, irregularly 2-septate, with 1 or 2 indistinct but some what large oil drops; $25-36 \times 9-11$ u., translucent, olive-brown, the middle cell about 15-17u. long, barrel-shaped; end cells about $7-8 \mathrm{u}$. long, obtuse-conic; paraphyses sparse, indistinct, filiform.

On leaves of Bromelia Pinguin L. Herbarium University of Illinois (Stevens) No. 4329. Cornell University. Explorations of Porto Rico (Whetzel, Kern and Toro) No. 25.36. University of Porto Rico Bxplorations of Santo Domingo (Kern and Toro). No 194, and $20 \%$. 
On Caraguata sp. (C. Romerguére Fungi selecti exsiccati No. 5s4t.) South America.

6. Asterina Melastomacearum Ryan.

The fungus Asterina. Melastomacearum sp. nov. is deseribed by Ryan (Mycol. 16: 186. 1924) on leaves of Miconia racemosa (Aubl.) DC. and H. impetiolaris (Sw.) D. Don., respectively. Two specimens of this fungus have been examined by the writer (Porto Rico Fungi (Stevens) Nos. $70.3 \%, 375$ ) and both agree with the description given by Arnaud (Les Asterinés I: 168. 1918) for Asterina Melastomatis Lév. The fact that this fungus is very common in other parts of the world on members of the Melastomacece, makes more certain the possibility that Asterina Melastomacearum Ryan is the same as Asterina Melastomatis Lév., in which case the former becomes a synonym of the latter for reason of priority (Plate I, figs. $8,9 \& 10$ ).

\section{EXPLANATION OF PLATE I}

Figere 2.-mingramatic sketch of a leaf of Chrysobalanus lcaco showing the distribution of colonies of Leprieurina radiata. $\times 1$.

Figlas 3.--Spores of Lepricurina radiata sp. nov. Notice the persistent sporophore on one of the spores. $\times$ soo.

Frgure 4.-Ascus and spores of Hicrothyriun Psychotriac (Ryan) comb. nor. $\times 800$.

Figtre 5.-Diagramatic sketeh of a leaf of Paychotriae sp. showing colonies of aticrothyrium Psychotrine. (Leaf $\times .5$, colonies $\times 2$. )

Fu(ivR: 6.-A perithecium of Toroa dimerosporioides (Speg.) Syd. showing method of de. liscing. Also the setaelike character of the mycelium is shown. $X 95$.

Fialere 7.-Two spores of Toroa dimerosporioides. $\times 800$.

Figtine 8.- Mycelium and hyphopodia of Asterina Melastomatis Irev. $Y$ sth.

Fiacre 9.-An aseus with spores of Lsterina Melastomatis. $\times 800$.

Frave: 10.-Two spores of Asterina Jelastomatis. $\times 800$. 

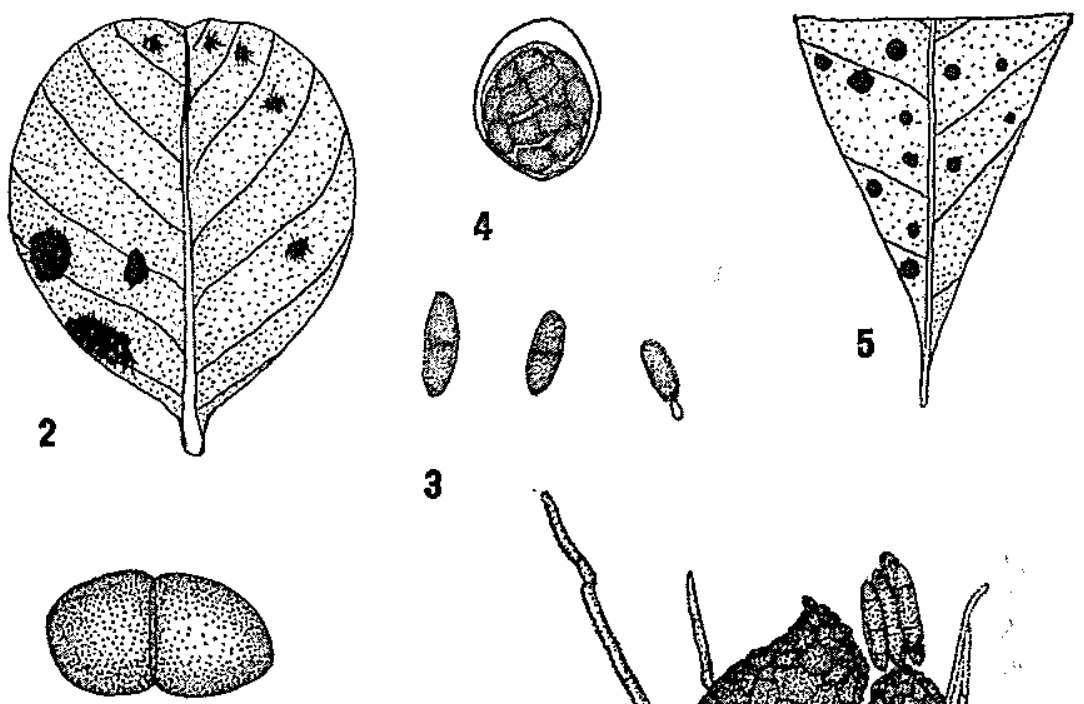

3
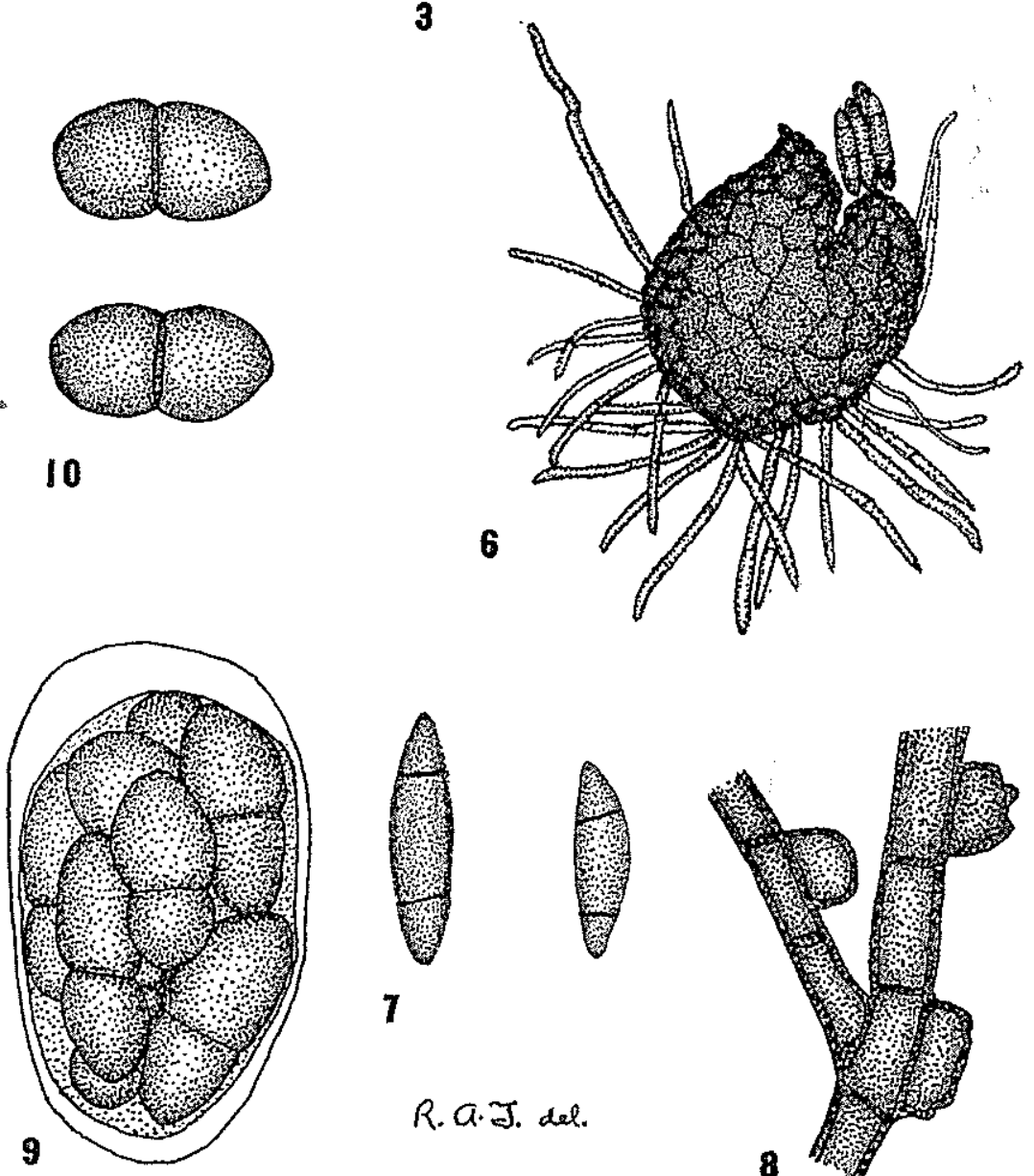

7

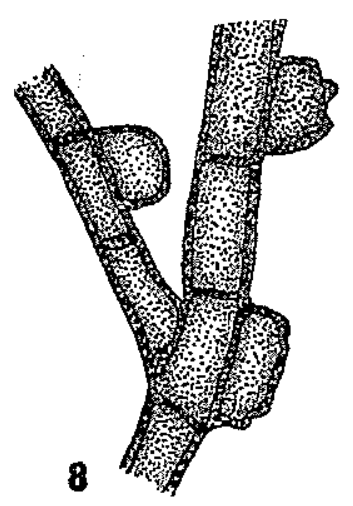

PLATE I 